\title{
Response of Pinus uncinata Recruitment to Climate Warming and Changes in Grazing Pressure in an Isolated Population of the Iberian System (NE Spain)
}

\author{
Author(s): J. Julio Camarero and Emilia Gutiérrez
}

Source: Arctic, Antarctic, and Alpine Research, 39(2):210-217. 2007.

Published By: Institute of Arctic and Alpine Research (INSTAAR), University of Colorado

DOI: 10.1657/1523-0430(2007)39[210:ROPURT]2.0.CO;2

URL:

http://www.bioone.org/doi/full/10.1657/1523-

0430\%282007\%2939\%5B210\%3AROPURT\%5D2.0.CO\%3B2

BioOne (www.bioone.org) is an electronic aggregator of bioscience research content, and the online home to over 160 journals and books published by not-for-profit societies, associations, museums, institutions, and presses.

Your use of this PDF, the BioOne Web site, and all posted and associated content indicates your acceptance of BioOne's Terms of Use, available at www.bioone.org/page/terms_of_use.

Usage of BioOne content is strictly limited to personal, educational, and non-commercial use. Commercial inquiries or rights and permissions requests should be directed to the individual publisher as copyright holder. 


\section{Response of Pinus uncinata Recruitment to Climate Warming and Changes in Grazing Pressure in an Isolated Population of the Iberian System (NE Spain)}

\author{
J. Julio Camarero*\$ and \\ Emilia Gutiérrez† \\ *Corresponding author. Unidad de \\ Recursos Forestales, C.I.T.A., Gobierno \\ de Aragón, Apdo. 727, 50080 Zaragoza, \\ Spain \\ jjcamarero@ipe.csic.es \\ $\dagger$ Departament d'Ecologia, Facultat de \\ Biologia, Universitat de Barcelona, \\ Avda. Diagonal 645, 08028 Barcelona, \\ Spain. \\ emgutierrez@ub.edu \\ \$Present address: Aragón I+D, Instituto \\ Pirenaico de Ecología, CSIC, Avda. \\ Montañana 1005, Zaragoza 50192, \\ Spain
}

\begin{abstract}
To infer future changes in the distribution of tree species in response to climatic variability, we need an understanding of the recruitment dynamics and their climatic controls at the species' distribution limit. We studied the recruitment processes in an isolated population of Pinus uncinata Ram. located at the southwestern limit of the species' distribution in Europe (Iberian System, NE Spain). We assessed (1) the temporal patterns of pine recruitment, and (2) how climate influenced recruitment. To reconstruct the recent recruitment episodes and to assess the climatic influence on recruitment and radial growth we employed dendrochronological methods. We mapped, measured the size, and estimated the age of all $P$. uncinata individuals located within a $50 \mathrm{~m} \times 40 \mathrm{~m}$ plot. Additional age data were obtained from individuals located in four nearby $20 \mathrm{~m} \times 20 \mathrm{~m}$ plots. The main episodes of tree establishment (early 1960s, late 1980s) coincided with low radial growth during a period with reduced grazing pressure. Grazing pressure and tree recruitment were not related at the spatiotemporal scale of this study. High May, August, and September minimum temperatures and high April precipitation were positively associated with recruitment, whereas high maximum April and June temperatures were negatively associated with recruitment. The studied population was in equilibrium with climate until the late 1990s, one of the warmest decades in the 20th century, when recruitment decreased despite the availability of suitable sites for establishment and the presence of reproductive individuals. We suggest that latesummer temperatures might have a non-linear negative threshold effect on recruitment rather than a linear effect. Despite increasing evidence of climateinduced recruitment episodes in isolated cold mountain forests, threshold effects of temperature on recruitment may imply limited range shifts of these populations in response to climate warming.
\end{abstract}

\section{Introduction}

Understanding current forest dynamics is essential to realistically forecast the effects of climate variation on tree populations. Paleoecologists and forest ecologists have found evidence of range shifts of tree species in response to past climate variation, mostly upward or northward displacements in response to climate warmings (Payette and Filion, 1985; Kullman, 2002; Shiyatov, 2003; Bekker, 2005). Consequently, many forest ecologists have assumed that a species' actual niche is similar to its potential niche, which would happen if climate was the main determinant of the present tree species distribution. In reality, many species' distribution limits are not in equilibrium with climate because they are often limited by additional factors such as disturbances (Davis, 1984; Loehle and LeBlanc, 1996).

Our ability to predict climate-induced shifts of tree populations is limited by an insufficient understanding of the effects of climate variability on tree recruitment (Brubaker, 1986). The effects of climate variability on tree recruitment may differ greatly depending on the spatiotemporal scale of study (Daniels and Veblen, 2004). For instance, climatic extremes may cause sudden declines of recruitment at local scales, especially in populations growing near the species limit of climatic tolerance, whereas the effects of long-term trends at large spatial scales may not become so evident (Meehl et al., 2000; Kullman, 2005). Climatic influences on recruitment have not been properly identified for periods ranging from decades to centuries because of the difficulty of reconstructing climate-induced changes. However, both climate and local disturbances (e.g., grazing) influence the recruitment dynamics of tree populations (Camarero and Gutiérrez, 1999). Hence, historical data such as dendrochronological reconstructions of recruitment events could provide insights about the recent dynamics at small spatial scales of tree populations located near the species distribution limit.

The research on recruitment dynamics is a priority in the case of isolated populations located at the limit of the species' geographical range because these stands may be more sensitive to recent climate warming if they are located near the limit of the species' climatic tolerance (Brubaker, 1986). Isolated tree populations of pine species restricted to high elevations become isolated from each other on different mountains separated by unsuitable habitat, with consequent reduced gene flow and genetic differentiation (Oline et al., 2000). The response of recruitment to climate variability at decadal scales in these isolated tree populations 


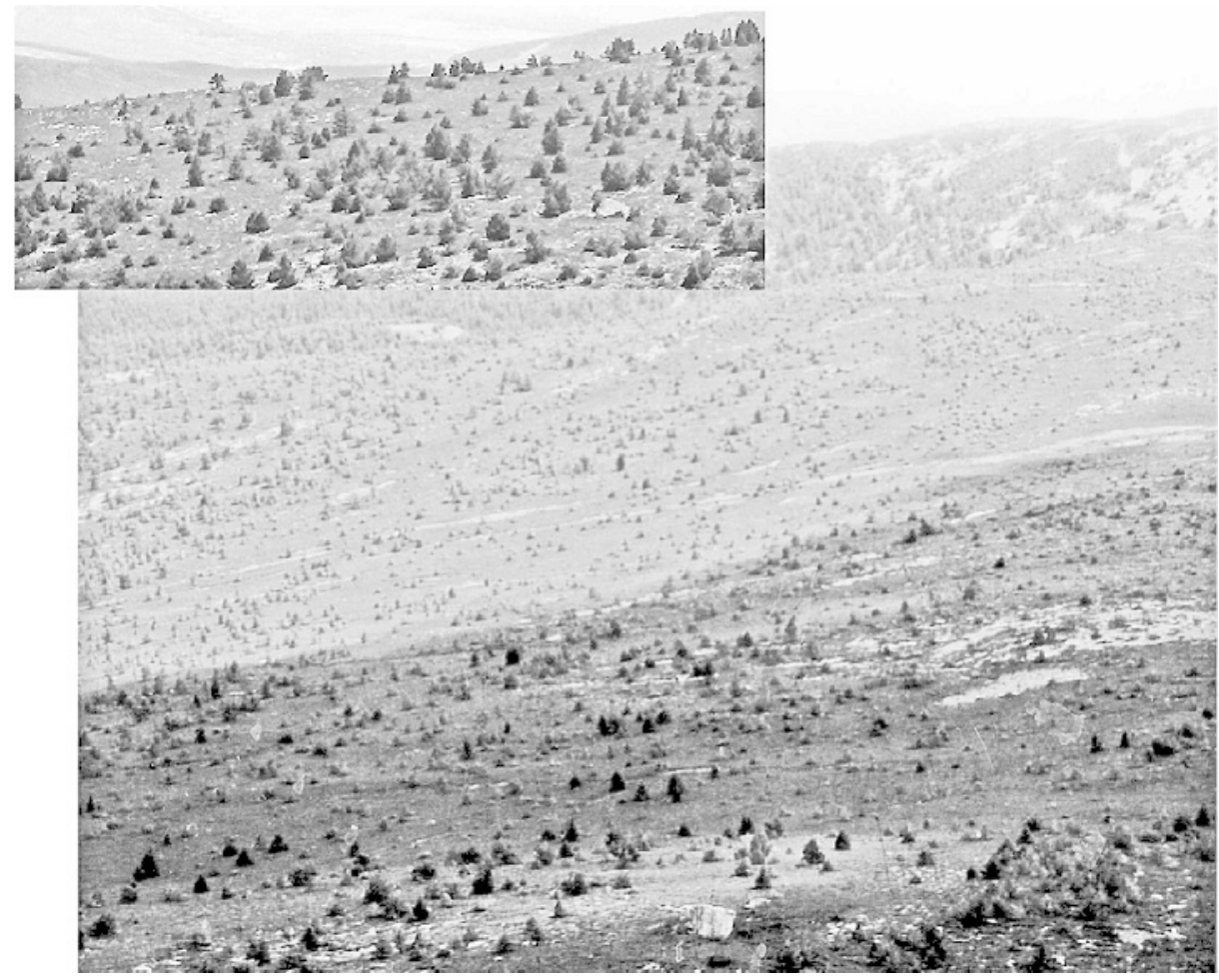

FIGURE 1. General view of the study area including a detailed view of the expanding Pinus uncinata population (inset).

might be affected by their isolation history and genetic differentiation. In addition, the greater sensitivity of stands at the species' range limit may be a result of the fact that climate is expected to be among the main constraints on tree recruitment in these populations. Recruitment is among the most critical determinants of the rate of forest shift to climatic change. Tree recruitment has been shown to be more sensitive to climate than adult mortality in harsh environments, where competition is low, because recruitment has lower climatic thresholds than adult mortality (Lloyd, 1997). However, the temporal dynamics of recruitment have not been carefully investigated in most tree species, and specifically in isolated stands (Veblen, 1992). In addition, tree recruitment in harsh environments might be also modulated by positive feedbacks at small spatial scales (Camarero et al., 2000; Smith et al., 2003; Bekker, 2005).

In most European ranges instrumental records have shown a sharp temperature rise since the 1940s (Diaz and Bradley, 1997), especially in SW Europe, where several Pinus species have been present in the Iberian Peninsula at least since the early Holocene (Peñalba, 1994). Hence, current climate change might affect the recruitment ability of these mountain pine stands in SW Europe. Currently, an isolated population of Pinus uncinata Ram. forms the SW distribution limit of the species, and it is located in the northern Iberian System, NE Spain (Fig. 1). The distribution area of $P$. uncinata encompasses the E Alps, the Pyrenees, and the Iberian System (Fig. 2). In Spain, subalpine forests in the Pyrenees form its main distribution area. The studied population currently occupies $115 \mathrm{ha}$, and it is located $150 \mathrm{~km}$ from the nearest $P$. uncinata forests in the Pyrenees. This forest is formed by sparse old P. uncinata individuals intermingled with Pinus sylvestris $\mathrm{L}$. However, recent $P$. uncinata colonization of non-forested areas has been observed (Fig. 1). Ceballos (1968) noted a natural expansion of $P$. uncinata in the study area during the 1930s, which was confirmed by aerial photographs (years 1946, 1957, 1984, 1990) of the study area showing an increase of tree cover.
P. uncinata is a shade-intolerant species that colonizes all kinds of soils (Ceballos and Ruiz de la Torre, 1979). Its smallwinged seeds are primarily dispersed by wind in late winter, and seedling emergence occurs in April-May. Two features make this species a good invader: (1) a short pre-reproductive period, and (2) frequent large crops every 2-4 years. The age of the oldest individuals is ca. 850 years in the Pyrenees and ca. 500 years in the study area. In this paper, we aimed at describing the temporal dynamics of an isolated population of $P$. uncinata at its southwestern distribution limit in the Iberian Peninsula. Specifically, we assessed: (1) the temporal patterns of recent recruitment, and (2) how climate influenced recruitment.

\section{Study Area}

The stand studied $\left(42^{\circ} 01^{\prime} \mathrm{N}, 02^{\circ} 44^{\prime} \mathrm{W}, 2040 \mathrm{~m}\right.$ a.s.1.) is located on moraine sediments. The moraine deposits are mostly vegetated and located near lakes of glacial origin. The substratum consists of Lower Cretaceous sandstones and quartzitic conglomerates. The study site was selected because it was a recently colonized area according to the maximum age of pine recruits where no signs of recent disturbances (fire, grazing, logging) were observed. The effect of topographical factors on tree recruitment through their influence on the abiotic environment may be regarded as minimal because the study area was relatively flat (mean slope $5^{\circ}$ ). The climate is continental (meteorological data were supplied from the Vinuesa station situated $12 \mathrm{~km}$ from the study site, $41^{\circ} 55^{\prime} \mathrm{N}, 02^{\circ} 46^{\prime} \mathrm{W}, 1107 \mathrm{~m}$ a.s.l., temperature data, 1961-1983, and precipitation data, 1961-1986). The annual precipitation is $1400 \mathrm{~mm}$ with July-August minima (Ortega Villazán, 1992). The annual mean temperature is $2{ }^{\circ} \mathrm{C}$, with the highest and lowest mean temperatures in July $\left(12{ }^{\circ} \mathrm{C}\right)$ and January $\left(0{ }^{\circ} \mathrm{C}\right)$, respectively. In December 1998 , mean snow depth $( \pm \mathrm{SD})$ in the study site was $11.3 \pm 8.1 \mathrm{~cm}$. Dominant winds are from W, N, and NW. The soils are acidic and shallow. Most forests in the 

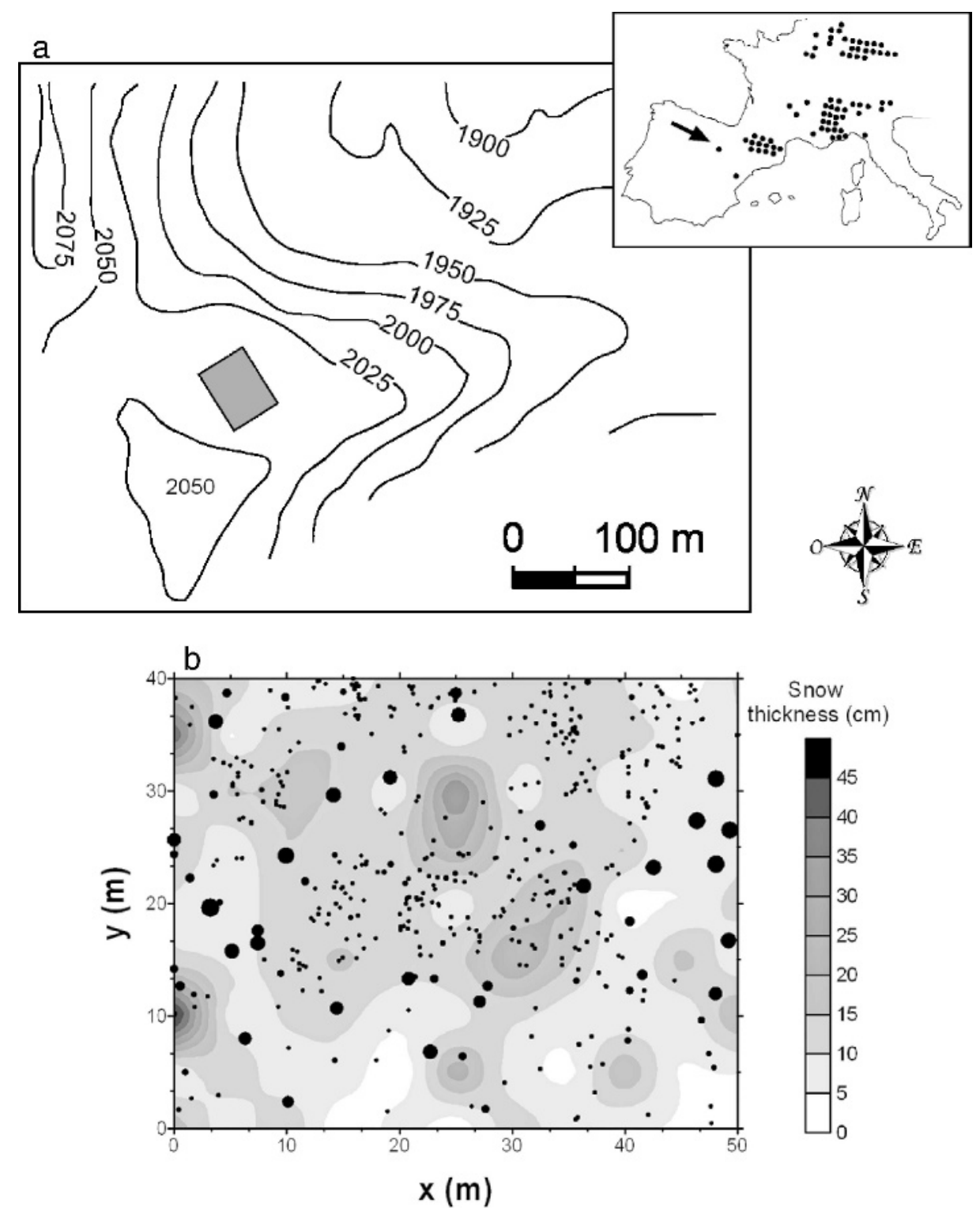

FIGURE 2. (a) Geographic distribution of $P$. uncinata in SW Europe, including the location of the study plot $\left(42^{\circ} 01^{\prime} \mathrm{N}, 02^{\circ} 44^{\prime} \mathrm{W}\right.$; see the arrow in the inset). (b) Location of all individuals sampled within the $50 \mathrm{~m} \times 40 \mathrm{~m}$ rectangular plot. The size of the circles is directly proportional to the tree height (the small points are seedlings), and the contour map shows the snow thickness in December 1998.

area are dominated by $P$. sylvestris and Calluna vulgaris (L.) Hull in the understory.

Palynological studies in the Northwest Iberian System have shown an increase in pine cover during the 20th century due to a decrease in grazing pressure and to climate warming (Gil García et al., 1996). However, the relevance at small spatiotemporal scales of these factors in the recent expansion of pines in this area has not yet been quantified. Historical data show that the current livestock number in the study area is ca.15\% of that recorded in the 18th century (Catastro del Marqués de Ensenada, 1752).

\section{Methods}

\section{SAMPLING PROCEDURES}

We mapped and measured the size (diameter at $1.3 \mathrm{~m}, d b h$; height, $h$ ), of all individuals located within a $50 \mathrm{~m} \times 40 \mathrm{~m}$ rectangular plot (Fig. 2). The plot was subjectively placed at the margin of the expanding $P$. uncinata population where intense recruitment has taken place during the past 50 years. The $x$ and $y$ plot axes were arranged along NW-SE and SW-NE directions, respectively. We also estimated the age of all $P$. uncinata individuals located within the plot. Additional age data were estimated for individuals located in four $20 \mathrm{~m} \times 20 \mathrm{~m}$ plots located at $5 \mathrm{~m}$ from the corners of the $50 \mathrm{~m} \times 40 \mathrm{~m}$ plot. No stumps were found within the plots. All browsing traces were recorded on a categorical scale (presence/absence). P. uncinata individuals were classified as mature $(d b h>17.5 \mathrm{~cm})$, poles $(7.5<$ $d b h<17.5 \mathrm{~cm})$, saplings $(d b h<7.5 \mathrm{~cm}, h>0.5 \mathrm{~m})$, seedlings $(h<$ $0.5 \mathrm{~m}$ ), dead trees, or krummholz. To sample and find small seedlings $(h<0.2 \mathrm{~m})$, the plots were subdivided into $1-\mathrm{m}^{2}$ quadrats. We also recorded if each stem was bearing or had produced cones, and related age (5-yr classes), and the frequency of trees per age class with cones. In December 1998, the maximum snow thickness was noted in every point within the $50 \mathrm{~m} \times 40 \mathrm{~m}$ plot using a $1 \mathrm{~m} \times 1 \mathrm{~m}$ grid $(n=2000$ sample points). A contour map of snow thickness in December 1998 was built using kriging.

\section{RELATIONSHIPS BETWEEN RECRUITMENT, RADIAL GROWTH, AND CLIMATE}

To reconstruct recent recruitment dynamics and quantify the climatic influence on recruitment and radial growth, we employed dendrochronological procedures. We built a chronology using the 
oldest trees within the plots (ca. 50 yrs old), and mature trees from the same population located $200 \mathrm{~m}$ apart. Two cores per tree were taken from perpendicular directions at $1.3 \mathrm{~m}$. They were prepared and cross-dated following standard dendrochronological procedures (Fritts, 1976). Tree-ring widths were measured to the nearest $0.01 \mathrm{~mm}$. Cross-dating and measurement quality were validated using COFECHA (Holmes, 1983). All ring-width series were filtered with a cubic smoothing spline function with 32-yr stiffness and a $50 \%$ frequency cutoff. Sample size was constant throughout the second half of the 20th century ( $n=20$ mature trees, $65 \%$ of them were located inside the plots). Autoregressive modeling was then performed on detrended series, which mostly showed autocorrelation of order 1. The final residual chronology was obtained using ARSTAN (Cook, 1985).

To estimate the age of seedlings we tagged them and counted their annual internodes to allow their future monitoring. The age of the remaining trees was estimated taking cores at $1.3 \mathrm{~m}$ with pith and cross-dating them. Their final ages were estimated as the sum of the number of cross-dated rings from 1.3-m cores plus the number of internodes up to the base. To calibrate the estimated age based on the number of annual whorls, we cut basal sections from the root collar of saplings and poles growing outside the plots $(n=20)$. The sections were sanded and the tree-rings were counted. Both age estimates were positively correlated $\left(R^{2}=0.22\right.$, $P=0.03)$ with a mean $4 \mathrm{yrs}$ underestimate for the internode counts. Kullman (1983) reported a similar underestimate (1-5 yrs) for P. sylvestris recruits. Following Lloyd (1997), the temporal resolution on the estimates of the germination dates was checked calculating the $95 \%$ confidence interval $( \pm 1.3 \mathrm{yrs})$ of the age-basal diameter power regression $\left(\right.$ age $=11.8$ diameter $^{0.3}, R^{2}=0.82, P<$ $0.0001, n=434)$. We used 5 -yr time classes as the finest resolution to take into account uncertainties in age estimates. The age distribution of trees located inside the $50 \mathrm{~m} \times 40 \mathrm{~m}$ plot did not differ significantly from that of trees placed in the four $20 \mathrm{~m} \times$ $20 \mathrm{~m}$ plots $(P>0.05$, Kolmogorov-Smirnov test). Therefore, both data sets were combined in a single age distribution.

Any inference based on age structures must be done with caution because they are produced by changes in recruitment and mortality (Veblen, 1992). We used recruitment residuals instead of raw age data to account for temporal patterns of sapling mortality, and because the relationships between climate and residuals were stronger than those based on raw data. Recruitment residuals were obtained using an exponential function for the period 1950-1999, excluding the oldest trees to remove the effect of outliers (age $\left.=1.810^{-7} \mathrm{e}^{(0.08 \text { time })}, R^{2}=0.18, P=0.0025\right)$. Residuals were converted into 5 -yr time classes. The exponential model explained the variance better than a power function $\left(R^{2}=\right.$ $0.17)$. The exponential model assumes constant recruitment and mortality. Other studies have used a similar approach to account for recruitment underestimates due to the disappearance of dead seedlings not detected in later censuses (Hett and Loucks, 1976; Bergeron and Gagnon, 1987; Szeicz and MacDonald, 1995).

To describe the climate-recruitment relationships we used monthly climatic data (maximum and minimum temperatures, total precipitation) from "Embalse de Cuerda del Pozo" station, located $16 \mathrm{~km}$ from the study site $\left(41^{\circ} 53^{\prime} \mathrm{N}, 02^{\circ} 42^{\prime} \mathrm{W}, 1150 \mathrm{~m}\right.$ a.s.1., 1963-1996 data), because of its long and complete series (missing data: temperature, 2.2\%; precipitation, 0.2\%). Climate data and missing values were estimated for the 1950-1997 period using data from "Soria" station, located $36 \mathrm{~km}$ from the study site $\left(41^{\circ} 46^{\prime} \mathrm{N}, 02^{\circ} 29^{\prime} \mathrm{W}, 1080 \mathrm{~m}\right.$ a.s.1.), because data from both stations were highly related $\left(R^{2}=0.32-0.86, P<0.05\right)$. They were transformed into 5 -yr classes using means for temperature or totals for precipitation. The relationships between grazing, monthly climatic variables, and recruitment were quantified with the Spearman rank correlation coefficient $\left(r_{s}\right)$ for 5 -yr classes. Finally, to compare $P$. uncinata recruitment and grazing pressure we used a 5-yr grazing series for the 20th century. The grazing series was built summing for 5-yr classes the number of grazing cattle (including sheep and goats) recorded in the historical archives from Villoslada de Cameros, a nearby village located $12 \mathrm{~km}$ from the study site. This rural community has experienced the same decrease in livestock number during the 20th century as most similar areas in the Iberian System (Lasanta Martínez et al., 1996).

\section{Results and Discussion}

\section{STRUCTURE AND RECRUITMENT}

Both bimodal $d b h$ and height $(h)$ distributions were observed, with maximum frequencies for $d b h<1 \mathrm{~cm}$ and $h<1 \mathrm{~m}$, and minor peaks for $d b h=15-20 \mathrm{~cm}$ and $h=4-5 \mathrm{~m}$. The distributions of $d b h$ and $h$ suggested the existence of two cohorts, corresponding to seedlings and poles and mature individuals. Seedlings dominated the recently colonized area at the spatiotemporal scale of this study because they were $83 \%(n=362)$ of all living individuals $(n=436)$. Such abundance of recruits is a typical feature of a stand initiation stage (Oliver and Larson, 1990). We also found 34 saplings, 14 krummholz individuals, 13 poles, and 13 mature trees. However, we located only 3 stems of mature dead individuals, which were well preserved and did not show signs of logging or fire scars. The age of the dead trees corresponded to the time of stand initiation, i.e. the early 1950s. Browsing signals were rare and restricted to saplings. No pine younger than 15 yrs bore cones, whereas at least $50 \%$ of pines older than 25 yrs did produce cones. Comparatively, $50 \%$ of pines older than 55 yrs produced cones in alpine treelines (Camarero, 1999).

\section{GRAZING IMPACTS ON PINE RECRUITMENT}

The oldest individuals in the study site were established in the early 1950s, when grazing pressure was still high (Fig. 3). However, we cored trees at least 350 yrs old in the nearby stands which form a continuous forest located $100-500 \mathrm{~m}$ from the isolated population. Thus, $P$. uncinata has colonized a new area where it had not been established during the first half of the 20th century. Our findings concur that the first $P$. uncinata expansion in the study area was during the 1930s, which was related to a decrease in grazing pressure (Ceballos, 1968). If $P$. uncinata individuals take $15-20$ yrs to become reproductive in the study site, the trees recruited in the study site during the 1950s might come from seeds produced by trees established in the 1930s expansion. Since 1950, no significant relationship was found between recruitment and grazing $\left(r_{s}=-0.46, P=0.15\right)$, despite the oldest pines being within the plots recruited when grazing started a declining trend. The recruitment-grazing negative relationship became stronger, but still not significant, when comparing grazing data of the previous 5 -yr period with recruits number of the following period $\left(r_{s}=-0.56, P=0.09\right)$. Grazing and climate were uncorrelated at the spatiotemporal scale of this study. In summary, the absence of browsing signals in most pine recruits and the lack of significant relationships between grazing and recruitment or climate strengthens the case that recent recruitment may be mainly controlled by climate. Grazing was not impacting tree recruitment at the small spatial scale of the study during past decades. However, the regional reduction in grazing pressure during the late 20th century probably facilitated 


\section{a) Temporal dynamics}

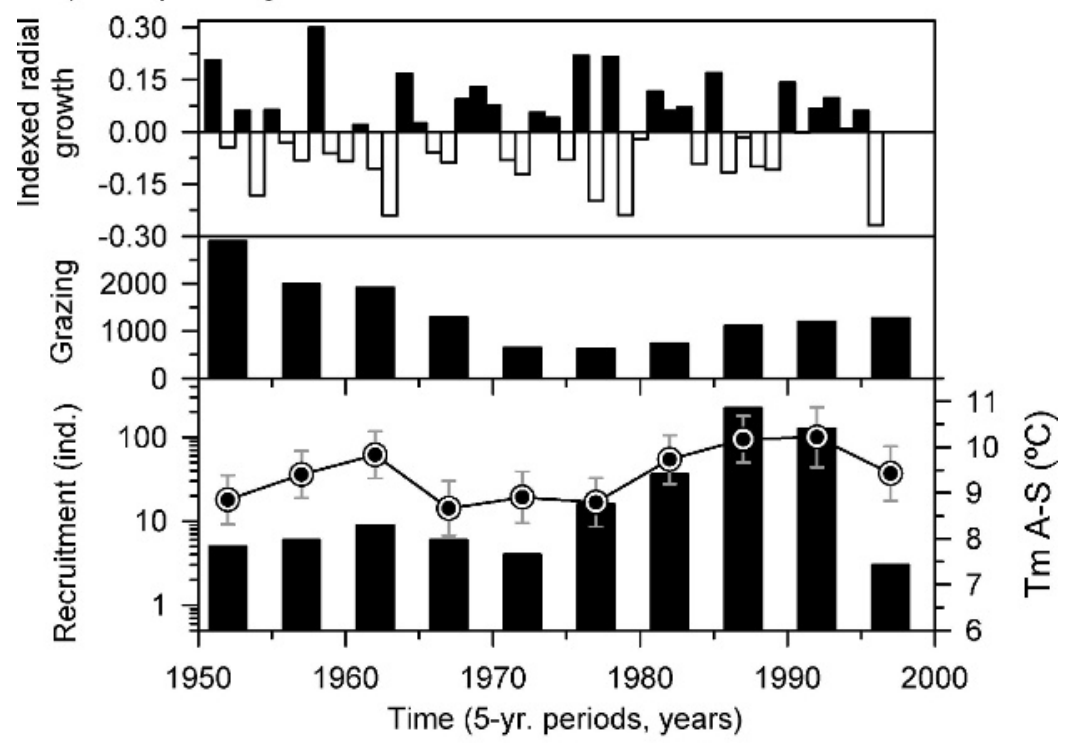

b) Climate-recruitment relationships

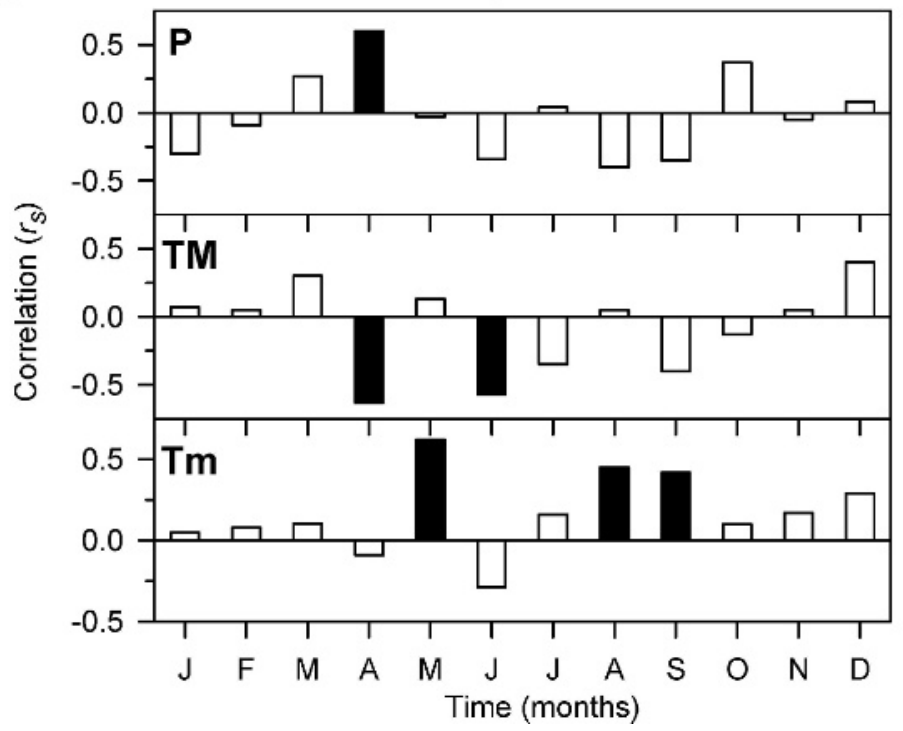

FIGURE 3. Climate, grazing data, and $P$. uncinata radial growth and recruitment. (a) Growth and grazing (number of grazing cattle) are compared with recruitment (bars) and mean August-September minimum temperature (line) grouped in 5-yr periods. Error bars are SE. (b) Correlations $\left(r_{s}\right.$, Spearman coefficient) between monthly climatic variables $(\mathrm{P}$, precipitation; TM and $T m$, mean maximum and minimum temperatures, respectively) and recruitment residuals for 5 -yr periods $(n=9)$. Black bars mean $P<0.05$.

the current reforestation in formerly grazed mountain areas. The relevance of land-use changes as a stronger driver on forest increase at regional scales compared to climate warming has been illustrated for treeline ecotones in the Scandes Mountains (Hofgaard, 1997). Therefore, future studies should encompass several spatiotemporal scales to assess the relative importance of changes in grazing pressure and climate on forest expansion.

\section{CLIMATE INFLUENCES ON PINE RECRUITMENT}

The decrease in grazing pressure coincided with the start of the pine colonization during the 20th century, which suggests that climate became the main factor controlling forest expansion in the study area once grazing pressure dropped below a certain threshold (Motta and Nola, 2001). The recruitment increase in the late 1950s and early 1960s observed in the study site was also detected in Pyrenean alpine treeline ecotones dominated by $P$. uncinata in response to increasing May temperatures but before any major decrease in grazing pressure (Camarero and Gutiérrez, 1999, 2004). Therefore, climate seems to be the main driving factor of forest expansion in this isolated stand and in high-elevation alpine treelines under moderate to low grazing pressures. Similar results have been observed in boreal and subalpine forests in northern Europe (Kullman, 1983; Zackrisson et al., 1995; Stöcklin and Körner, 1999; Shiyatov, 2003). Furthermore, the recruitment drop in the early 1970s was observed both in the study sites and in the Pyrenees, and coincided with cold summers and falls due to intense cyclonic conditions in NE Spain (Camarero, 1999). Seedlings recruited in the late 1980 s dominated the population, but tree recruitment has decreased since this decade. The recruitment pulses in the late 1980s corresponded to low values of radial growth because both variables were not significantly related. Climate conditions that facilitated $P$. uncinata establishment were different from those that enhanced radial growth as has been found in other tree species (Earle, 1993; Daniels and Veblen, 2004).

We have found a strong recruitment response in the studied isolated population, which suggests that its recruitment history has been very sensitive to the past decrease in grazing pressure and the recent climate warming. Further research is needed to determine if 
this response is due to the contrasting structure and dynamics between expanding isolated populations at the limit of the species' geographical range and forest stands at the core of the range. Historical isolation in "mountain islands" may also produce genetic differentiation (Oline et al., 2000), including a greater sensitivity to climate.

Temperature was the main climatic factor controlling $P$. uncinata recruitment in the study site at decadal scales. High May, August, and September minimum temperatures and high April precipitation were positively associated with recruitment, whereas high maximum April and June temperatures were negatively associated with recruitment (Fig. 3). In continental systems, winter frosts and warm summer temperatures are important mortality factors of pine seedlings (Frey, 1983). Both factors affected $P$. uncinata recruitment, especially high minimum temperatures in spring and late summer which enhanced recruitment. This might be explained by an elongation of the growing season in late summer or because of lower cold-induced damage in spring when seedlings establish. The positive effect of April precipitation may also be related to an enhancement of seedling survival and establishment.

The overwhelming role of minimum temperatures for successful recruitment in this stand might be due to the much colder temperatures registered in the study area as compared with Pyrenean sites located at similar elevation (Ortega Villazán, 1992). Despite the similar climate-recruitment relationships found at the isolated stand and in alpine $P$. uncinata treeline ecotones (Camarero and Gutiérrez, 1999), we did not detect any positive effect of summer rainfall on recruitment in the study site. Therefore, water stress may be a greater constraint on P. uncinata recruitment in alpine treelines under Mediterranean influence than in this isolated high-elevation stand under continental influence. Further studies are needed to separate the effects of climate on the two main processes determining tree recruitment, i.e. seed production (e.g., masting) and seedling establishment.

The recruitment of new individuals into openings occurred almost continuously. The expanding pine population has colonized open microsites within or near $C$. vulgaris mats which reduce understory light and may prevent pine recruitment (Camarero et al., 2005). Doche (1984) observed a similar colonization pattern for P. sylvestris seedlings. In the eastern Pyrenees, Puig (1982) found the following factors favoring $P$. uncinata regeneration: low herbaceous cover, and reduced grazing pressure. Thus, recruitment may have responded to climate variability in the study site because the understory was relatively "invasible." Prévosto et al. (2003) reached a similar conclusion studying $P$. sylvestris invasion of grasslands. Zackrisson et al. (1995) also emphasized that an adequate regeneration niche (Grubb, 1977) was necessary for successful recruitment of $P$. sylvestris in boreal forests. They suggested that the interference of the understory on $P$. sylvestris recruitment might explain the temporal lags $(20-30 \mathrm{yrs})$ that they found between warm periods and recruitment peaks. We did not find long climate-recruitment lags for $P$. uncinata which indicates that the interference of the forest floor vegetation on recruitment was much stronger for $P$. sylvestris in boreal forests than for $P$. uncinata in the studied mountain stand (Camarero et al., 2005). In addition, these two pine species might show different responses of seed production and germination to climate. Other indirect interactions between $P$. uncinata seedlings and $C$. vulgaris might have affected the observed recruitment patterns. For instance, Scots pine recruits suffered fewer snow blight attacks thus showing lower mortality inside C. vulgaris patches than on lichens (Burdon et al., 1994). Finally, trees may facilitate leeward seedling establishment by depositing wind-blown snow thus allowing forest encroachment as has been observed in similar harsh environments such as alpine treelines (Smith et al., 2003; Bekker, 2005). In the study site, snow-accumulation patterns were not related to seedling density, but more data are needed to account for the year-to-year variability in snow depth and its relationship with forest structure.

We noted reduced rates of recruitment in the late 1990s despite the availability of suitable sites for establishment, and the presence of reproductive individuals. Therefore, the studied population was in equilibrium until the 1990 s, one of the warmest periods during the past century, when warming may have exerted a negative non-linear effect on recruitment if a threshold in the temperature-recruitment relationship was surpassed. In species with long life spans such as $P$. uncinata, it is critical to preserve reproductive adults in order to "store" recruitment potential (Warner and Chesson, 1985). Such a storage effect allows a high population growth during favorable climatic periods in sites with low adult population density (Dovčiak et al., 2005). Pinus uncinata is restricted to mountains in SW Europe, and it reaches its southernmost limit of distribution in the Iberian System, NE Spain. Managers should try to "store" the recruitment potential of these stands, protecting reproductive individuals and providing suitable sites for regeneration.

\section{Conclusions}

Grazing pressure and tree recruitment were not related at the spatiotemporal scale of this study, and the oldest individuals in the study site established under moderate to high grazing pressure in a nearby village. Thus, the decrease in grazing pressure since the mid-1900s did not explain the recent regeneration pulses. Nevertheless, the decline in grazing pressure coincided with the start of the pine colonization during the past 20th century, which suggests that climate became the main triggering force of the recent tree colonization once grazing pressure dropped below a certain threshold. Climate was then the main driving force of the recent pine expansion at small spatial scales, but this process may have been facilitated by the reduction in the number of grazing cattle. The presence of a relatively "invasible" understory and the grazing decline may be prerequisites for further expansion of pine populations.

Our findings emphasize the need for care in making predictions implying an increase of tree recruitment in cold mountain areas in response to climate warming. Non-linear relationships between climate and recruitment and interactions of tree seedlings with the understory species might explain why $P$. uncinata and other tree species restricted to cold mountain areas show moderate range shifts in response to climate warming. Both aspects merit additional investigation if we aim to forecast future range shifts of tree species. Threshold responses of recent pine recruitment to current climate warming in isolated high-elevation populations should not be discarded despite the remaining uncertainties of climate vs. grazing as past triggers.

\section{Acknowledgments}

We are grateful to the Camarero-Martínez family, J. Tardif, P. R. Sheppard, J. Contreras, J. A. Ramos, and "Villoslada de Cameros" Town Hall. CICyT (AMB95-0160) and EU (ForMAT, Contrat ENV4-CT97-0641) projects funded this work. Camarero acknowledges with gratitude the support of a postdoctoral INIADGA contract. We also thank the associate editor and two anonymous reviewers for their comments. 


\section{References Cited}

Bekker, M. F., 2005: Positive feedback between tree establishment and patterns of subalpine forest advancement, Glacier National Park, Montana, U.S.A. Arctic, Antarctic, and Alpine Research, 37: 97-107.

Bergeron, Y., and Gagnon, D., 1987: Age structure of red pine (Pinus resinosa Ait.) at its northern limit in Québec. Canadian Journal of Forest Research, 17: 129-137.

Brubaker, L. B., 1986: Responses of tree populations to climatic change. Vegetatio, 67: 119-130.

Burdon, J. A., Wennstrom, A., Muller, W. J., and Ericson, L., 1994: Spatial patterning in young stands of Pinus sylvestris in relation to mortality caused by the snow blight pathogen Phacidium infestans. Oikos, 71: 130-136.

Camarero, J. J., 1999: Growth and regeneration patterns and processes in Pinus uncinata Ram. treeline ecotones in the Pyrenees and in an isolated population in the western distribution limit in Spain. Ph.D. thesis. University of Barcelona: Barcelona, Spain.

Camarero, J. J., and Gutiérrez, E., 1999: Structure and recent recruitment at alpine forest-pasture ecotones in the Spanish Central Pyrenees. Écoscience, 6: 451-464.

Camarero, J. J., and Gutiérrez, E., 2004: Pace and pattern of recent treeline dynamics: response of ecotones to climatic variability in the Spanish Pyrenees. Climatic Change, 63: $181-200$

Camarero, J. J., Gutiérrez, E., and Fortin, M.-J., 2000: Spatial pattern of subalpine forest-alpine grassland ecotones in the Spanish Central Pyrenees. Forest Ecology and Management, 134: $1-16$.

Camarero, J. J., Gutiérrez, E., Fortin, M.-J., and Ribbens, E., 2005: Spatial patterns of tree recruitment in a relict population of Pinus uncinata: forest expansion through stratified-diffusion. Journal of Biogeography, 32: 1979-1992.

Catastro del Marqués de la Ensenada, 1752: Tomo n. 73. Archivo Histórico Provincial de Soria, Soria, Spain.

Ceballos, L., 1968: Una nueva localidad española del Pinus uncinata Ram. Collectanea Botanica, 9: 213-220.

Ceballos, L., and Ruiz de la Torre, J., 1979: Árboles y arbustos de la España peninsular. Madrid: E.T.S.I.M., 512 pp.

Cook, E. R., 1985: A Time Series Analysis Approach to Tree-Ring Standardization. Ph.D. thesis. University of Arizona: Tucson, $171 \mathrm{pp}$.

Daniels, L. D., and Veblen, T. T., 2004: Spatiotemporal influences of climate on altitudinal treeline in northern Patagonia. Ecology, 85: 1284-1296.

Davis, M. B., 1984: Climatic instability, time lags, and community disequilibrium. In: Diamond, J., and Case, T. J. (eds.), Community Ecology. New York: Harper and Row, 269-284.

Diaz, H. F., and Bradley, R. S., 1997: Temperature variations during the last century at high elevation. Climatic Change, 36: 254-279.

Doche, B., 1984: Demography of Pinus sylvestris in the Calluna vulgaris heathlands of the granitic montane level (French Central Massif). Documents Cartographie Ecologie, 27: 21-42.

Dovčiak, M., Frelich, L. E., and Reich, P. B., 2005: Pathways in old-field succession to white pine: seed rain, shade, and climate effects. Ecological Monographs, 75: 363-378.

Earle, C. J., 1993: Forest dynamics in a forest-tundra ecotone, Medicine Bow Mountains, Wyoming. Ph.D. dissertation. University of Washington: Seattle.

Frey, W., 1983: The influence of snow on growth and survival of planted trees. Arctic and Alpine Research, 15: 241-251.

Fritts, H. C., 1976: Tree Rings and Climate. New York: Academic Press, $567 \mathrm{pp}$.

Gil García, M. J., Tomás Las Heras, R., Núñez Olivera, E., and Martínez Abaigar, J., 1996: Acción humana sobre el medio natural en la Sierra de Cameros a partir del análisis polínico. Zubia, 8: 29-41.
Grubb, P. J., 1977: The maintenance of species-richness in plant communities: the importance of the regeneration niche. $B i$ ological Reviews of the Cambridge Philosophical Society, 52: 107-145.

Hett, J. M., and Loucks, O. L., 1976: Age structure models of balsam fir and eastern hemlock. Journal of Ecology, 64: 1029-1044.

Hofgaard, A., 1997: Inter-relationships between tree line position, species diversity, land-use and climate change in the central Scandes Mountains of Norway. Global Ecology and Biogeography Letters, 6: 419-429.

Holmes, R. L., 1983: Computer-assisted quality control in treering dating and measurement. Tree-Ring Bulletin, 43: 68-78.

Kullman, L., 1983: Short-term population trends of isolated treelimit stands of Pinus sylvestris L. in central Sweden. Arctic and Alpine Research, 15: 369-382.

Kullman, L., 2002: Rapid recent range-margin rise of tree and shrub species in the Swedish Scandes. Journal of Ecology, 90: 68-77.

Kullman, L., 2005: Pine (Pinus sylvestris) tree-line dynamics during the past millennium - a population study in west-central Sweden. Annales Botanici Fennici, 42: 95-106.

Lasanta Martínez, T., Arnáez Vadillo, J., Ortigosa Izquierdo, L. M., and Oserín Elorza, M., 1996: Consecuencias geoecológicas del abandono agrícola en Cameros Viejo (Sistema Ibérico). Zubia, 8: 61-85.

Lloyd, A. H., 1997: Response of tree-line populations of foxtail pine (Pinus balfouriana) to climate variation over the last 1000 years. Canadian Journal of Forest Research, 27: 936-942.

Loehle, C., and LeBlanc, D., 1996: Model-based assessments of climate change effects on forests: a critical review. Ecological Modelling, 90: 1-31.

Meehl, G. A., Karl, T., Easterling, D. R., Changnon, S., Pielke, R., Changnon, D., Evans, J., Groisman, P., Knutson, T. R., Kunkel, K. E., Mearns, L. O., Parmesan, C., Pulwarty, R., Root, T., Sylves, R. T., Whetton, P., and Zwiers, F., 2000: An introduction to trends in extreme weather and climate events: observations, socioeconomic impacts, terrestrial ecological impacts, and model projections. Bulletin of the American Meteorological Society, 81: 413-416.

Motta, R., and Nola, P., 2001: Growth trends and dynamics in sub-alpine forest stands in the Varaita Valley (Piedmont, Italy) and their relationships with human activities and global change. Journal of Vegetation Science, 12: 219-230.

Oline, D. K., Mitton, J. B., and Granta, M. C., 2000: Population and subspecific genetic differentiation in the foxtail pine (Pinus balfouriana). Evolution, 54: 1813-1819.

Oliver, C. D., and Larson, B. C., 1990: Forest Stand Dynamics. New York: McGraw-Hill, 467 pp.

Ortega Villazán, M. T., 1992: El Clima del Sector Norte de la Cordillera Ibérica: Estudio Geográfico de la Sierra de la Demanda a la del Moncayo. Valladolid: Universidad de Valladolid, $359 \mathrm{pp}$.

Payette, S., and Filion, L., 1985: White spruce expansion at the tree line and recent climatic change. Canadian Journal of Forest Research, 15: 241-251.

Peñalba, M. C., 1994: The history of the Holocene vegetation in northern Spain from pollen analysis. Journal of Ecology, 82: $815-832$.

Prévosto, B., Hill, D. R. C., and Coquillard, P., 2003: Individualbased modelling of Pinus sylvestris invasion after grazing abandonment in the French Massif Central. Plant Ecology, 168: 121-137.

Puig, J. N., 1982: Recherches sur la dynamique des peuplements forestiers en milieu de montagne: contribution à l'étude de la régénération en forêt d'Osséja. Ph.D. thesis. Université Paul Sabatier: Toulouse, $192 \mathrm{pp}$.

Shiyatov, S. G., 2003: Rates of change in the upper treeline ecotone in the Polar Ural Mountains. Pages Newsletter, 11: $8-10$. 
Smith, W. K., Germino, M. J., Hancock, T. E., and Johnson, D. M., 2003: Another perspective on altitudinal limits of alpine timberlines. Tree Physiology, 23: 1101-1112.

Stöcklin, J., and Körner, C., 1999: Recruitment and mortality of Pinus sylvestris near the arctic tree line: the role of climatic change and herbivory. Ecological Bulletin, 47: 168-177.

Szeicz, J. M., and MacDonald, G. M., 1995: Recent white spruce dynamics at the subarctic alpine tree line of north-western Canada. Journal of Ecology, 83: 873-885.

Veblen, T. T., 1992: Regeneration dynamics. In: Glenn-Lewin, D. C., Peet, R. K., and Veblen, T. T. (eds.), Plant Succes- sion, Theory and Prediction. London: Chapman \& Hall, $152-187$.

Warner, R. R., and Chesson, P. L., 1985: Coexistence mediated by recruitment fluctuations: a field guide to the storage effect. The American Naturalist, 125: 769-787.

Zackrisson, O., Nilsson, M. C., Steijlen, I., and Hörnberg, G., 1995: Regeneration pulses and climate-vegetation interactions in nonpyrogenic boreal Scots pine stands. Journal of Ecology, 83: 469-483.

Ms accepted April 2006 